\title{
熄刺激で誘発される眼球運動; 特に大脳辺縁系の
}

\section{2，3の核についての比較観察†}

\author{
中西和 仁*, 覦学**
}

I・はじめに

今日までの解剖学的及び生理学的研究によると，竖上 皮より上行する求心性線維は咱神経となり嗅球に達す る。嗅球からの求心性線維は嗅索を形成し, 㖵索は内側

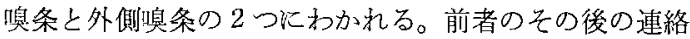
はな和不明の点があるが，終板傍回に入り，さらに内側 前脳束を介して視床下部に連絡するといわれている。こ れに対し，外側嗅条は海馬傍回の前端䑙 (鈎)，梨状野， 扁桃体に達するといわ机ている(小池上，1975 a)。

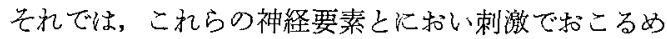
まい，平衡失調の成立機序はどの様な関係をもつもので あ万らか？それが命回の私達の研究目的である。すで に，私達はウサギ扁桃核内側部の反覆電気刺激により， 動物はに拈い刺激(アリナミン) に過做に反応し，眼振 様眼球運動をひき抗こすこと，並びにこのよらな状態と なった動物は adrenaline にも過剩に反応し，この薬剂 の静注で眼振が出現するよらたなることを報告した（表

1, 表 2 , 表 4 参照) (中西, 檜1979)。

このような事実を参照して私達はに拈い刺激で扣こる めまい，平衡失調の機序に痈桃核，特にその队側核群は 重要な役割を果するのと考えている。

それでは，その他の神経要素, 特に大脳辺縁系の諸核 はに扣い刺湤で扣こるめまい。平衡失調の機序にどのよ らな関連をもつものであるらか？また，それらは扁桃核 内側部とどのよらな関係があるのであるうか?

本諭文では，この問題を明らかにするため，次の策駼 を行った。すなわら，ウサギ海馬，届桃核外側部，中隔 野及び手綱核のそれぞれに電極を插入し，それぞれに反 覆電気刺激を加え，におい刺激による眼球の平衡障㫪の 出現の有無を檢討した。また，これらの動物で adrenaline 静注による眼球の平衡障害発現の状況を钼察した。 ここで, adrenaline を用いたのは次の聂山による。すな わら，(1私達のウサギを用いた研究によると，に扎い刺

†A further study on olfaction-related nystagmic response in rabbits with reference to ENG findings produced by intravenous adrenaline and inhalation of vapor of liquid garlic

*Nakanishi $\mathrm{K}$, and Hinoki $\mathrm{M}$.

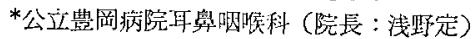

**京都大学医学部耳鼻相喉科学教等 (主任 : 檜学教授)

Equilibrium Res. Vol. 40(2)
激でおこる眼球の平衡障害の成立に，扁桃核内側部，特 にその中にふくまれる adrenergic components は重要 な役割を果す(中西，檜1979)。頭頸部外伤によるめ まい例で，“に技い負荷平衡試験” が陽性所見を示した ものはいずれも adrenaline 耐性を低下し，この薬剤の 投与で容易に平衡失調を誘発又は増大する(检，他1981) などが自験されているからである。

以下得られた成績を述べる。

II. 成

績

（1）実験動物，実験方法

黑眼成熟当ザ（体重 $2 \sim 2.5 \mathrm{~kg}$ ）21羽を用いた。こ れらのウサギは海馬反覆電気刺激ウサギ ( 8 羽), 雇桃 核外側部反覆電気刺激ウサギ ( 3 羽), 中隔野反覆電気 刺激ウサギ(5羽) 及び手綱核反覆電気刺激ウサギ（5 羽）の4群に䄪けられる。これらの動物では何れる左側 火電極が刺入され，以下のべる条件で電気刺激が反覆負 荷されている。電極の插入は SAWYER の atlas に従 って行った。また，眼球運動の出現を確認する意味で， 次にのべるような条件で脳波 (EEG) と眼振電図 (ENG) を同時記録してある。すなわ方，各群とも左側海馬，左 側中悩洞様体及び右側前頭皮質に電極が雨入されてい る。この他に海馬反稪電気刺激ウサギでは左側前頭皮質

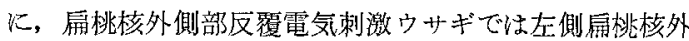
側部に，中隔野反覆電気刺激ウサギでは左側中隔野に，

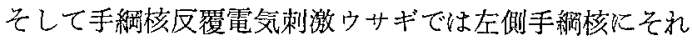
でれ電極が挿入され，EEG が記録されている。

これまでの経験によると，眼球運動が電気刺激や薬物 (例点ば adrenaline) 注射の結果, 誘発あるいは增強さ れる場合には，脳波には覚醒反心応が伴われる。従って， 安号操作でおこった眼振電図上の所見が，人工的所産で ないことを確諗するにはこの力法は有力である（中西 1976, 中西, 檜, 他 1978, Hinoki, Nakanishi et al. 1978)。

さて, 脳の各部への電気刺激の条件は以下のごとくで ある。すなわち，1 $\mathrm{msec}, 200 \mathrm{~Hz}$ の矩形波，3V，30秒 の条件で, 海馬, 卌桃核外側部, 中隔野及び手綱核にそ れぞれ電気刺激を1日1回の割合で，連日反得して10回 加えられた。

に扣い刺激としてはアリナミン溶液 $(2 \mathrm{ml}$ 中 $10 \mathrm{mg}$ の Diallylsulfide を含む) を有い，これを $1 \mathrm{~cm}^{3}$ 大の綿 
球に浸し，動物の鼻孔前 $1 \mathrm{~cm}$ に括き，2 分閒経鼻孔的 飞嗅刺激を加えた。この操作による脳活動性の変化と眼 球運動の変化を上述した脳の各部より誘導した EEG と ENG 用いて記録，観察した。

またここれらの動物炕数ける中枢神経系の adrenergic components の活動性とに打い刺激で报こる眼球の平衡 障害の相関を知るためて，同じウサギの耷静脈より微量 $(0.005 \mathrm{mg} / \mathrm{kg})$ の adrenaline を注射し，この薬郕に対 して成立する眼球運動の誘発や変動を ENG 角いて記 録したが，同時に上述の EEG を記録し，ENG の所見 を確認した。

なお，比括い刺激実験（上述）上 adrenaline 静注実 験は同じに，2 時間以上の間隔を和いて行われてい る。

実験終了後、ウサギの脳を10\% formaline で固定し， 脳切片より刺激部位を確認している。

（2）に招い刺激, adrenaline 静注で誘発される眼振の 判定法

そ抬い刺激や adrenaline 静注による眼運動系への影 響の判定はこれまでに私達が報告した方法を用いて行っ た（中西，檜，他1978，中西，檜1979）。

すなるち，動物がに斿い刺激や adrenaline 静注を行 う前の30分間见示していた ENG 所見を基準とし，それ に対してに括い刺激後出るいは adrenaline 静注後30分 間炕出現する眼振の状態を比較して，促進，抑制，有意 の変化なしと記載した。(1)に物い刺激や adrenaline 静 注が眼運動系の活動性を促進したと判定したのは次の 3 通りの眼振の変動が扣こった場合で㘯る。すなわち，

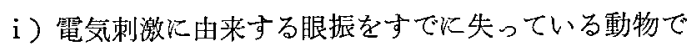
は，飞招い刺激や adrenaline 静注後に 5 ヶ以上の眼振 が誘発される場合，ii）電気刺激に由来する眼振が 10 ケ 以内残存している動物では，上述の操作でその打数の 2 倍以上の眼振が誘発される場合, iii) 電気刺激汇由来ず る眼振を10ケ以上残存している動物では，上述の操作で その打数の1.5倍以上の眼振が誘発される場合, である。 (口)和い刺激や adrenaline 静注により眼運動系の活動 性が抑制されたと判定されるのは次の 3 通りの眼振の変 動が括こった場合である。すなわち，i）電気刺激に由 来する眼振が 5 ケ以内残存している動物では, に沶い刺 激や adrenaline 静注後眼振が消失した場合，ii）電気刺 激に由来する眼振を 5 ケ〜10ケ残存している動物では， 上述の操作で誘発される眼振数が前者の $1 / 3$ 以下となる

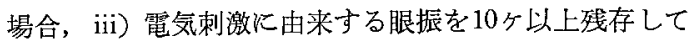
いる動物では，上述の操作で誘発される眼振数が前者の 眼振数の $1 / 2$ 以下となる場合,である。の及び问の何 れの項にも属岂ない場合住，火括い刺激や adrenaline 静注により眼運動系は有意の影響をうけがたかったもの
と判定した。

以上の基準が妥当であるか否がさらに今後の検討を まつ必要があるが，同時記録している脳波所見や同じ時 期に扢こなった視運動眼振の変動を参照すると，この基 準による判定は大きなあやまりをるたらするのではない と考えている。

(3) 得られた成績

(A) 海馬反覆電気刺激ウサギにおける成績；

(a) 沉打い刺激で誘発される眼球運動の成續：海馬電 気刺激を経験していないウサギ（8羽）では，に括い刺 激前30分間, 飞拉い刺激後30分間, 計60分間の観察で眼 振を示唆する異常眼球運動はみられていない。

この笂験に供したウサギは 8 羽全例が，海馬への反覆 電気刺激で電気刺激中止後に一定の潜時を拈いて眼振様 眼球運動（電気刺激後眼振）を出現している。また，反 覆電気刺激により全例電気刺激前にも眼振 (特発眼振) を示すよらになっている。すなわち, 眼運動系はこの操 作で活動性え進の状態を来すようになったと考えてよ い。

さて，この脳への電気刺激反覆を中止し，一定時日 (平均 2 日) を経過すると, 反覆電気刺激により出現し ていな特発性眼振 (上述) は消失するか, 又は出現して もその度合が著しく減少している。この時期飞，におい 刺激を負荷する実験を行なった。この際，反覆電気刺激 に上り出現していた特発眼振を既に失っていたものは 1 羽 $(12.5 \%)$ ，この眼振が出現していたるのは 7 羽(87.5 \%)である。

上述の判定基準を用い, 海馬反覆電気刺激ウサギ（8 羽）に和けるに蛙い刺激負荷の影響を観察すると, 表 1 のようになる。表示するように，反覆電気刺激による特 発眼振が出現していた 7 羽の動物では, に招い刺激で 1 羽 (14.3\%) 性振が促進され，1羽 (14.3\%) はそれ が抑制された。残りの 5 羽 (71.4\%)では同じ操作で眼 振は有意の影響をうけなかった。反覆電気刺激で出現し ていた特発眼振を既《失っていた 1 羽では，に招い刺激 で眼振は誘発されなかった。

換言すると，海馬反覆電気刺激ウサギではにおい刺激 で眼運動系の活動性亢進が強力に増強されることは少な いことが判明した。

(b) adrenaline 静注で誘発される眼球運動の成績：上 記の 8 羽のウサギは海馬へ反覆電気刺激を加党る前に は，全例 ENG 上泪眼を示唆する異常眼球運動をみと めていない。またこれらの動物に adrenaline の静注 を行なってる ENG 上飞眼振を示唆する異常眼球運動は 誘発されなかった。

さて，これらのウサギの海馬に反澓して電気刺激を加 えると，全例眼振が出現している。この8 羽中 4 羽 
表 1 飞扣い刺激で誘発される異常眼球運動(眼振); 海馬反覆電気刺激ウサギ，扁桃核外側部反覆 電気刺激ウサギ，中隔野反覆電気刺激ウサギ 及び手綱核反覆電気刺激ウサキににおるる観察

\begin{tabular}{|c|c|c|c|c|}
\hline 動 物 眼 振 & 促 進 & 抑 制 & $\mid \begin{array}{l}\text { 有意の変 } \\
\text { 糸なし }\end{array}$ & 計 \\
\hline $\begin{array}{l}\text { 海馬反覆電気刺 } \\
\text { 激ウササギ }\end{array}$ & $(12.5 \%)$ & $(12.5 \%)$ & $(75.0 \%)$ & $\begin{array}{c}8 \\
(100 \%)\end{array}$ \\
\hline 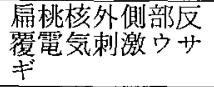 & 0 & 0 & $\begin{array}{c}3 \\
(100 \%)\end{array}$ & $\begin{array}{c}3 \\
(100 \%)\end{array}$ \\
\hline $\begin{array}{l}\text { 徧桃核内側部反 } \\
\text { 復電気刺激ウサ } \\
\text { ギ } \\
\text { (中西, 檱 1979) }\end{array}$ & $(75.0 \%)$ & 0 & $(25.0 \%)$ & $\begin{array}{c}8 \\
(100 \%)\end{array}$ \\
\hline $\begin{array}{l}\text { 中隔野反覆電気 } \\
\text { 刺激ウササ萃 }\end{array}$ & $(20.0 \%)$ & 0 & $(80.0 \%)$ & $\begin{array}{c}5 \\
(100 \%)\end{array}$ \\
\hline $\begin{array}{l}\text { 手綱核区覆電気 } \\
\text { 剌激りサザ }\end{array}$ & $(80.0 \%)$ & 0 & $(20.0 \%)$ & $\begin{array}{c}5 \\
(100 \%)\end{array}$ \\
\hline
\end{tabular}

表 2 ad̀renaline 静注で誘発される異常眼球運動 (眼振)；海馬反覆電気刺激ウサギ，扁桃核外 側部反覆電気刺激当サギ，中隔野反覆電気刺 激ウサギ及び手秘核反覆電気刺激ウサギに扰 惊観察

\begin{tabular}{|c|c|c|c|c|}
\hline 動 物 眼 振 & 促 進 & 抑 制 & $\mid \begin{array}{l}\text { 有意の変 } \\
\text { 㗢なし }\end{array}$ & 計 \\
\hline $\begin{array}{l}\text { 海馬反覆電気刺 } \\
\text { 激ウササギ }\end{array}$ & $(62.5 \%)$ & $(12.5 \%)$ & $(25.0 \%)$ & $\begin{array}{c}8 \\
(100 \%)\end{array}$ \\
\hline $\begin{array}{l}\text { 䁩桃核外側部反 } \\
\text { 復電気刺激ウササ } \\
\text { キ }\end{array}$ & 0 & 0 & $\begin{array}{c}3 \\
(100 \%)\end{array}$ & $\begin{array}{c}3 \\
(100 \%)\end{array}$ \\
\hline 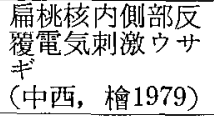 & $(75.0 \%)$ & 0 & $(25.0 \%)$ & $\begin{array}{c}8 \\
(100 \%)\end{array}$ \\
\hline $\begin{array}{l}\text { 中隔野反覆電気 } \\
\text { 刺激方ササ }\end{array}$ & $(20.0 \%)$ & 0 & $\left(\begin{array}{c}4 \\
(80.0 \%)\end{array}\right.$ & $\begin{array}{c}5 \\
(100 \%)\end{array}$ \\
\hline $\begin{array}{l}\text { 手綱核反覆電気 } \\
\text { 刺激ウササキ }\end{array}$ & $(80.0 \%)$ & 0 & $\mid \begin{array}{c}1 \\
(20.0 \%)\end{array}$ & $\begin{array}{c}5 \\
(100 \%)\end{array}$ \\
\hline
\end{tabular}

(50\%) は adrenaline 注射時電気刺激化由来する眼振を 既に失って括り，残りの 4 羽 (50\%) はこの種の眼振が な和出現していた。

さて，上述の判定基準に従いこれらのウサギの眼運動 系に対する adrenaline 注射の影響を観察すると表 2 の よらな戊績がえられた。すなわち，反覆電気刺激による 眼振をな扣出現していた動物では，adrenaline 静注によ り 2 羽 (50\%) は眼振が促進され，1 羽(25\%) はそれ が抑制された。残りの 1 羽 (25\%) では同じ操作により 眼振に有意の変動をみとるなかった。

電気刺激による眼振を既に失っていた秱物では， adrenaline 注射で 3 羽 $(75 \%)$ は眼振が誘発され, 残り の 1 羽 (25\%) は眼振を出現しなかった。

Equilibrium Res. Vol. 40(2)
表 3 火特い刺激による眼振の変動と adrenaline 静注に上る眼振の変動の相関; 海馬反澓電気 刺激ウサギに拈ける観察

\begin{tabular}{|c|c|c|c|c|c|}
\hline \multicolumn{2}{|c|}{ 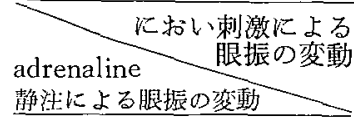 } & 促進 & 抑制 & $\begin{array}{l}\text { 有意の } \\
\text { 変動な } \\
\text { L }\end{array}$ & 計 \\
\hline 促 & 進 & 1 & 1 & 3 & 5 \\
\hline 抑 & 制 & 0 & 0 & 1 & 1 \\
\hline 有意 & $=2$ & 0 & 0 & 2 & 2 \\
\hline
\end{tabular}

換言すると，海馬への反覆電気刺激によりウサギは adrenaline 火過敏に反応するようになり，この薬剤注射 で眼振を比較的容易に出現することが判った。

(c) に沶い刺激㑇荷で誘発される眼振の变動と ad-

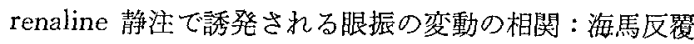
電気刺激ウサギ ( 8 羽) を対象とし，火执い刺激による 眼振の変動と adrenaline 静注によるそれの相関を観察 すると表 3 のらな成績が党られた。表示するよらに， におい刺激で执こる眼振と adrenaline 静注で括こるそ れの間には高い相関はみとめられなかった。すなわら， 8 羽中 1 羽 (12.5\%) では何れの操作でも眼振が促進さ れたが，残りの7羽 (87.5\%) では去の上らな関係を及 とめなかった。

(B) 扁桃核外側部反覆電気刺激ウサギに拈ける成績;

(a) に括い刺激で誘発される眼球運動の成續：扁桃核 外側部電気刺激を経験していないウサギ（ 3 羽）は，に 扣い刺激前30分間，に扣い刺激後30分間，計60分間の観 察で眼振を示唆する異常眼球運動はみられていない。

この実験に供したウサギは 3 羽全例が，扇桃核外側部 への反覆電気刺激で電気刺激中止後に一定の潜時を扣い て眼振様眼球運動 (電気刺激後眼振) を出現している。 なた，反覆電気刺激により全例電気刺激前にも眼振（特 発眼振)を出現するようになっている。すなわ方，眼運 動系はこの操作で活動性宁進の状態を来すようになった と考えてよい。

さて,この脳への電気刺激反覆を中止し，一定時日 (平均 2 日) を経過すると, 反覆電気刺激により出現し ていた特発眼振 (電気刺激前眼振) 法消失するか, 又は 出現してもとの度拿が著しく減少している。この時期 に、に就い刺激を角荷する夹験を行なった。

この際，反覆電氮刺激に上り出現していた特発眼振 （上述）を既に失っていたものは1羽 (33.3\%), この眼 振がな括出現していたものは2羽（66.7\%）であった。

ところで，先に述べた判定基準を用い，扁桃核外側部 反愎電気刺激ウサギ（３羽）に拈けるに扣い刺激負荷の 
影響を観察すると次の上らになる。すなわち，表１亿示 すように, 反覆電気刺激による特発眼振を出現していた 2 羽の動物では，に拉い刺激で眼振には有意の影響がみ られなかった。電気刺激による特発眼振を既に失ってい た 1 羽の動物で多，に拈い刺激で眼振は出現しなかっ た。

換言すると，屏桃核外側部反覆電気刺激ウサギでは, そ颃い刺激で眼運動系の活動性九進が増強され難いこと が判明した。

(b) adrenaline 静注で誘発される眼球運動の成績 : 上 記の3羽のウサギでは扁桃核外側部への反覆電気刺激前 には， $\mathrm{ENG}$ 上に眼振を示唆する異常眼球運動をみとめ ていない。またこれらの動物に adrenaline 竫注を行 ってむ, ENG 上眼振を示唆する異常眼球運動は誘発 されなかった。

上述したよらに、これらのウサギは扁桃核外側部への 反覆電気刺激を加之ると, 全例眼振を出現している。こ の 3 羽中 1 羽 (33.3\%) のウサギは adrenaline 注射時 電気刺激に由来する眼振を既汇失っており，残りの2 羽 (66.7\%) はこの種の眼振がな招出現していた。

さて, 上述の判定基準に従い, これらのウサギ( 3 羽) の眼運動系に対する adrenaline 注射の影響を観察する と次のよらになる。すなわち, 表 2 に示すよらに, 反覆 電気刺激により眼振を出現していた 2 羽の動物では， adrenaline 静注により既存の眼振は有意の影響をらけな かった。また，眼振を既に失っていた 1 羽の動物でも adrenaline 注射で眼振は誘発されなかった。

換言すると，鼠桃核外側部反覆電気刺激ではウサギの adrenaline 耐性に有意の変化はなくこの薬阂注射で眼 振は誘発又は堌強され難かった。

(c)におい刺激負荷で誘発される眼振の変動之 adrenaline 静注で誘発される眼振の変動の相関 : 扁桃核外

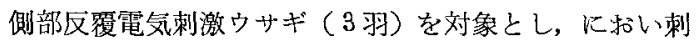
激による眼振の変動と adrenaline 静注によるそれの相 関を観察すると表4のよらな成績がえられた。表示する よらに,これらのウサギでは上記の 2 つの操作は眼振に 対し有意の影響を示さなかった。

（C）中隔野反覆電気刺激ウサギにおける成績；

(a) に扣い刺激で誘発される眼球運動の成績 : 中隔野 電気刺激を経験していないウサギ（5羽）では，に扣い 刺激前30分間, に打い刺激後30分間, 計60分間の観察て 眼振を示唆する異常眼球運動はみられていない。

この実験见供したウサギは 5 羽全例が，中隔野への反 覆電気刺激で電気刺激中止啳に一定の潜時を打いて眼振 様眼球運動（電気刺激後眼振）を出現している。また， 反覆電気刺激により全例電気刺激前に。眼振（特発眼 振)を出現するようになっている。すなおる，眼運動系
表 4 に执い刺激による眼振の変動と adrenaline 静注による眼振の変動の相関; 扇桃核外側部 反覆電気制激ウサギに牤ける観察

\begin{tabular}{|c|c|c|c|c|}
\hline 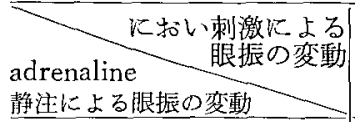 & 促進 & 抑制 & $\mid \begin{array}{l}\text { 有意の } \\
\text { 変動な }\end{array}$ & 計 \\
\hline 進 & $\begin{array}{c}0 \\
(6)\end{array}$ & $\left.\begin{array}{c}0 \\
0\end{array}\right)$ & $\begin{array}{c}0 \\
(0)\end{array}$ & $\begin{array}{c}0 \\
(6)\end{array}$ \\
\hline 抑 & $\left(\begin{array}{c}0 \\
0\end{array}\right)$ & $\left(\begin{array}{l}0 \\
0\end{array}\right)$ & $\left(\begin{array}{c}0 \\
(0)\end{array}\right.$ & $\left(\begin{array}{l}0 \\
0\end{array}\right)$ \\
\hline 有意の変動なし & $\begin{array}{c}0 \\
(0)\end{array}$ & $\begin{array}{c}0 \\
(0)\end{array}$ & $\begin{array}{l}3 \\
(2)\end{array}$ & $\begin{array}{l}3 \\
(2)\end{array}$ \\
\hline
\end{tabular}

注 : ( ) 内の数字は扁桃核内側部反覆電気刺激で 得られた成績（中西，檜1979）。

はこの操作で活動性儿進状態を来すよらになったと考え てよい。

さて，この脳への電気刺激反覆を中止 $し ， 一$ 定時日 (平均 2 日) を経過すると, 反覆電気刺激浮より出現し ていた特発性眼振（電気刺激剖）は消失するか, 又は出 現してもその度合が著しく減少している。この時期に， に扔い刺激を負荷する実験を行なった。この際，反覆電 気刺激により出現していた特発眼振（上述）を既に失っ ていたものは 1 羽 (20\%), この眼振がな和出現してい たものは 4 羽 $(80 \%)$ であった。

上述の判定基準を用い，中隔野反醅電気刺激ウサギ (5羽)に打けるに拈い刺激負荷の影響を観察すると， 表1のようになる。表示するように，反覆電気刺激によ る特発眼振を出現していた 4 羽の動物では，におい刺激 で1羽 (25\%) では眼振が促進されたが，3羽 (75\%) では眼振に有意の変動がみられなかった。

反覆電気刺激で出現していた眼振を既に失っていた 1 羽では，に扣い刺激で眼振は誘発されなかった。

換言すると，中隔野反覆電気刺激ウサギで红括い刺 激で眼運動系の活動性元進が増強される頻度は少ないこ とが判明した。

(b) adrenaline 静注で誘発される眼球運動の成績：上 記の5羽のウサギは中隔野への反覆電気刺激前には, 全 例 ENG 上飞眼振を示咬する異常眼球運動をみとめてい ない。またこれらの動物に adrenaline の静注を行な っても, $\mathrm{ENG}$ 上に眼振を示唆する異常眼球運動は誘発 されなかった。

さて，これらのウサギに中隔野への反覆電気刺激を加 えると全例眼振が出現している。この 5 羽中 1 羽(20\%) は adrenaline 注射時電気刺激に由来する眼振学既に失 って特り，残りの 4 羽 (80\%) はこの種の眼振がな搔出 現していた。

上述の判定基準に従い，これらのウサギ（5羽）の眼 
表 5 におい刺激による眼振の变動と adrenaline 静注による眼振の変動の相関; 中隔野反覆電 気刺激ウサギに和ける観察

\begin{tabular}{|c|c|c|c|c|}
\hline 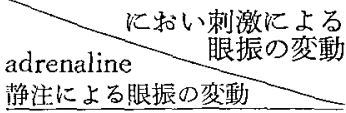 & 促進 & 抑制 & 有意の & 計 \\
\hline 進 & 1 & 0 & 0 & 1 \\
\hline 制 & 0 & 0 & 0 & 0 \\
\hline 有意の变動なし & 0 & 0 & 4 & 4 \\
\hline
\end{tabular}

運動系に対する adrenaline 注射の影響を観察すると表 2のよらな成績がえられた。すなわら, 反覆電気刺激に よる眼振を出現していた動物では，adrenaline 静注によ り 1 羽 (25\%) は眼振が促進され，残りの 3 羽 (75\%) では眼振に有意の変動をみとめなかった。電気刺激によ る眼振を既に失っていた 1 羽の動物では，adrenaline 注 射で眼振の誘発をみなかった。

換言すると，中隔野への反覆電気刺激を行って眼振を 出現するよらになっていたりサギでも adrenaline に過 敏に反応し，眼振を誘発又は増強するよらなことは少な かった。

(c) に扣い刺激負荷で誘発される眼振の変動之 $\mathrm{ad}$ renaline 静注で誘発される眼振の変動の相関: 中隔野反

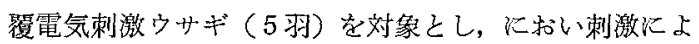
る眼振の変動と adrenaline 静注によるそ礼の相関を钼 察すると表5のよらな成結が兄られた。表示するよら に，に颃い刺激で既存の眼振が増強された1羽のりサギ では adrenaline 静注によっても眼振の増强がみられて いる。また, 前者の操作により眼振の誘発又は増強をみ なかったのこりの 4 羽では後者の操作たよって車眼振の 誘発又は增強をみていない。

(D)手綱核反覆電気刺激ウサギに和ける成績；

(a) に括い刺激で誘発される眼球運動の成績 : 手綱核 電気刺激を経騒していないウサギ ( 5 羽) は, 法い刺 激前30分間, 飞和い刺激後30分間, 計60分間の観察で眼 振などの異常眼球運動はみられていない。

この笑験に供したウサギは 5 羽全例が，手絧核への反 覆電気刺激で電気刺激中止後に一定の潜時を和いて眼振 様眼球運動（電気刺激後眼振）が出現している。また, 反覆電気刺激により全例が電気刺激前にも眼振（特発眼 振）が出現するよらになっている。すなわら，眼運動系 はこの操作で活動性元進状態を来すようになったと考え てよい。

さて, この脳への電気刺激反覆を中止し, 一定時日 (平均 2 日) 学経過すると, 反覆電気刺激汇より出現し
表 6 そ扣い刺激による眼振の変動と adrenaline 静注による眼振の変動の相関; 手綱核反覆電 気刺激ウサギに束ける観察

\begin{tabular}{|c|c|c|c|c|c|}
\hline \multicolumn{2}{|c|}{ 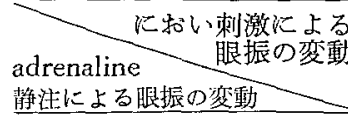 } & 促進 & 抑制 & 有意の & 計 \\
\hline 促 & 進 & 4 & 0 & 0 & 4 \\
\hline 抑 & 制 & 0 & 0 & 0 & 0 \\
\hline 有至 & & 0 & 0 & 1 & 1 \\
\hline
\end{tabular}

ていた特発性眼振（電気刺激前）は消失するか, 又は出 現してもその度合が著しく減少している。この時期に， に扣い刺激を負荷する実験を行なった。この際, 反覆電 気刺激により出現していた眼振 (上述) を既に失ってい たものは 2 羽 (40\%)，この眼振がな搔出現していたも のは3羽 $(60 \%)$ であった。

上述の判定基準に従い，手綱核反覆電気刺激ウサギ （5羽）に括子るに叔い刺激負荷の影響を観察すると， 表 1 のらになる。表示するように, 反輹電気刺激によ り出現していた特発眼振を出現していた 3 羽のうち， 2 羽 (66.7\%) はにおい刺激で眼振が促進され, 残りの1 羽 (33.3\%) は眼振に有意の変動をみなかった。反覆電 気刺激により出現していた特発眼振を既に失っていた 2 羽の動物では，いずれもに扔い刺激で眼振が誘発されて いる。

換言すると，手綱核への反覆電気刺激をらけたウサギ は，に和い刺激に鋭敏となりこの刺激を負荷すると眼 振が出現又性增大し, 腿運動系の活動性亢進が強力に增 強されることが判明した。

(b) adrenaline 静注で誘発される眼球運動の成績：上 記の 5 羽のウサギは手綱核への反覆電気刺激前住全例 $\mathrm{ENG}$ 上汇眼振などの異常眼球運動をみとめていない。

またこれらの動物に adrenaline の静注を行っても ENG 上K眼振を示晙する異常眼球運動は誘発されなか った。

さて，これらのウサギに手絧核への反覆電気刺激を加 えると, 全例眼振が出現している。この 5 羽中 3 羽 60 \%) は adrenaline 注射時電気刺激に由来する眼振を既 に失っており，残りの 2 羽 (40\%) はこの種の眼振がな 扣出現していた。

上述の判定基準に従い，手綱核反覆電気刺激ウサギ (5羽) の眼運動系に対する adrenaline 注射の影響を 観察すると，表2のようになる。すなわち，反覆電気剌 激による眼振を出現していた 2 羽の動物では，全例 adrenaline 静注により眼振が促進されている。 
電気刺激による眼振を既に失っていた 3 羽の動物で は, adrenaline 注射により 2 羽 $(66.7 \%)$ が眼振を出現 し，残りの 1 羽 (33.3\%)では眼振の誘発をみなかっ た。

换言すると，手綱核反覆電気刺激によりウサギは $\mathrm{ad}$ renaline に過敏に反応与るようになり，この薬剂注射で 容易に眼振を出現又は増強することが判った。

（c）におい刺激負荷で誘発される眼振の変動と $\mathrm{ad}^{-}$ renaline 静注で誘発される眼振の变動の相関: 手綱核反 覆電気刺激りサギ ( 5 羽) を対象とし，に扣い刺激によ る眼振の変動と adrenaline 静注によるそれの相関を観 察すると表 6 のよな成績がえられた。表示するよら に，火招い刺激で眼振が誘発されるか又は既存の眼振が 增強されたウサギ 4 羽では全例 adrenaline 静注によっ ても眼振の諉発又は堌強がみられた。また，前者の操作 により眼振が増強されなかった 1 羽は後者の操作によっ ても眼振の誘発をみていない。

換言すると，に掉い刺激で招こる眼振と adrenaline で㸝こるそれの間にはかなり高い相関があることが判明 した。

\section{III. 総括 と考案}

これまでの解剖学的並びに生理学的実験成績による と, 未暞嗅覚器 (嗅球及び嗅索) と大脳辺縁系の関係は 複雑であり，現在な叔不明の点も少なくない。

小池上 $(1965 \mathrm{a})$ の嗅球破壊でおこる变性線維の研究 によると，前梨状皮質，扁桃核周辺皮質，屚桃核の皮質 内側核群が末梢嗅覚器と直接的関係をもつという。

Kaada (1951) は, ネコの㖵球を電気刺激し, これに 対応する response を胲の各部位で記録している。この 実験の結果, negative potential を示す部位として, 嗅 索, 前梨状葉, 扁桃核周辺皮質, 㖵結節の前外側部があ り, positive potential を示す部位としては眼窩面, gyrus proccessus の下部内側面の脳梁下の領域をあげている。 この際, 電気的応答を示さなかった部位は, 海馬回の後 部, 脳梁膨大後野, 海馬, 中隔部及び帯状回の大部分で ある。

また，同じ研究者のサルを用いた検討では，嗅球の電 気刺激で fast negative spike の出現する分野としては, 㫧索外側, 中間嗅条に沿亏部分, 㖵結節の前外側部, 海 馬回の前端部などがあげられている。これに対し，第 II, 第吕の negative deflection がみられる部位として, 㖵索, 前頭皮質眼窩面後部, 嗅結節の前外側部, 島限, 海馬回の前端部がある。 positive deflection のるらかれ る部位は上記の negative zone のすぐ周辺部である。す なわち，前頭皮質の眼窩面，島前部，海馬回の一部，側 頭皮質極部内側面の脳梁下の一部などがこれに該当す る。
以上のように, 末梢嗅覚器と大脳辺縁系の関係以複雑 であり，動物の種類によっても線維連絡に多少差がみら れる。しかし，いずれの動物でる嗅球と関係の梁い脳分 野として扁桃核があげられていることは注目してよい。 そして，高木（1979）らの+ルを用いた電気生理学的実 験では, 嗅覚系求心路の神経要素として扁桃核は電視さ れている。

さて，小池上 (1962) によると，扇桃核は内側核群 (cortico-medial 群と内側主核) と外側核群（中間主核と 外側主核)に分けられる。

私達のウサギを用いた実験によると，扁桃核内側部の 反覆電気刺激により，ウサギは眼振を出現するようにな る。そしてこのような動物はに拈い刺激に対しても過 敏となりこの刺激で眼振を高率に出現又は增大するよ らになる(8羽中6羽，75\%)。むたここのような動物 は adrenaline 耐性を低下し，この薬剂の静注により眼 振を誘発又は堌強する(中西, 检1979)。

これに対し, 今回私達が得た成䋶によると, 動物は扇 桃核外側部に電気刺激を反覆加えられると眼振を出現す るよらになる。しかしここらの動物はに和い刺激に過 敏に反応せず，この刺激をあたえても眼振の誘発や増大 はみられない。また， adrenaline 耐性に有意の変化を示 さず,この薬剂を静注しても眼振の誘発, 増強はみてい ない。

以上の成績より，扁桃核内側部はにおい刺激でおこる 眼振の成立に重要な役割を果すが，外側部はこの刺激に 刘し眼振発現に重要な役割を果す部位とは考学難い。ま た，私達は先に報告した論文で，中枢神経系，とくに大 脳辺縁采化らくれる adrenergic components $の$ hyperreactivity は嗅刺激に対する眼振の発現に重要な条件で あることを指摘した（中西，检 1979）。この考光は今回 の実験成縝よりも支持される。そして，今回の成結及び 私達が先行行った報告（中西, 檜1979）は次の報告と矛 盾しない。すなわち, 小池上がのべている「扁桃核内側 部は視床下部交感带と密な連絡があり, 屚桃核外側部は 視床下部副交感带と関係が深い」といら報告と矛盾しな い(小池上 $1965 \mathrm{~b}$ )。

なお，以上の成績は次の諸家の報告にも関連する。す なかち，扁桃核に機能局在がないといら研究者がいるが (Gloor 1955), Kaada 5 (1954), Magnus, Lammers (1956), Ursin, Kaada (1960) では多少ともに機能局 在をみとめている。今回の成續は後者の考えを新しい資 料のるとに支持するものとして注目される。

さて, 上述したように, 㖵球からの求心性線維は嗅索 を形成し，これは内側嗅条と外側嗅条の2つにわかれる。 このらち外側嗅条よりの線維は海馬傍回前端部(鈎), さらには海馬傍回（前半分は梨状葉, 後半分は内㖵領) 
に達している。海馬傍回と海馬の間に注密接な解剖学的 関連があり，両者間には細い歯状回が存在するのみであ る。そして，内嗅領から海馬に直接あるい:崡状回を経 由して関接に神経線維が走行している (Holmes, Sharp 1969)。従って, 嗅受容器よりの求心性インパルスは嗅 球を介して多シナップス性に海馬に達する可能性があ る。もらろん，海馬が悬球と関係の深い脳分野であるか 否がついては, 研究者によって得られた成續が一定で ない。るた，動物の種類によってもその成績に差があ 万。

今回私達が得た成績では，海馬の反覆電気刺激によ り，8羽中 2 羽 (25\%) の動物はに牤い刺激に過钽とな り，この操作で眼振を増強又は減少している。しかし， 残りの6 羽 (75\%) の動物はに特い刺激に過敏となら ずここの制激で眼振は有意の変化を示していない。この 成績から直ちに海馬が嗅覚形成や嗔覚に関係する自律神 経系反応に無関係であるとは判定は出来ない。しかし， この成績は海馬は, 扁桃核内側部に較べて, 嗅覚及びそ れに関係のある体性神経反射户自律神経反応の出現によ り間接的な役割を果す脳分野であると推定することは可 能亡思う。

それではどの様な理由で上述した様な成績の差が得ら れるのであるらか。これに関しては次の事項が考えられ る。すなわち，両者いずれも嗅受容器との連絡を有する としても, 海馬は扁桃核内側部に較べて, 嗅受容器より 嗅球を介して終止する求心性線維が少ないことがその理 由のひとつであるう。そして，この考完は先に述べた末 梢嗅覚器と大脳辺縁系に関する諸家の研究成續よりみて 多妥当之考光尚。

次ににおい刺激で誘発される眼振と中隔野との関係に ついてのべてみたい。Meyer-Allison (1949) の鍍銀法 を用いた研究によると, 㖵索よりの求心性線維は中隔野 火直接終止しない。他方，嗅索よりわかれた外側拲条は 嗅結節に達するが，ここを出た求心性線維は中隔野に終 止するとの報告がある(House, Pansky 1967 a )。但し, 小池上によると，中隔野へ線維を送る嗅結節の部位は嘎 覚に直接的関係のない部分であるという（小池上 $(1975 \mathrm{~b})$ 。

以上の諸家の報告を参照すると，中隔野は直接嗅覚と 深い関連を有する脸分野であるとは断定しがたい。るち ろん，中隔野は脳弓や対角带核を介して海馬や扁桃核と のあいだに密接な線維連絡を有している。従って，嗅受 容器よりの求心性インパルスがこれらの諸核を介して間 接的に中隔野入伝光ら礼可可能性は否定できない。

さて，今回の私達のウサギの成績では中隔野に反㠅電 気刺激を加光ると，5羽中 1 羽 (20\%) はに和い刺激に 過敏となりこの刺激で眼振を増強している。またこ
の動物は adrenaline 耐性を低下し，この薬剤の静注に より眼振を增強している。これに対し，残りの4羽(80 \%)の動物は《招い刺激で眼振を誘発又は增強せず, adrenaline 静注でる ENG 上に有意の変化をみない。

以上の成䌐は，中隔野が和い刺激でおこる眼振の成 立に関連を有するとしても，その果す役割は，扁桃核内 側部に較べるとはるが少ないことを示唆している。 な括，中隔野反覆電気刺激りサギのらら，飞拈い刺激 で眼振の誘発がみられるものは adrenaline でもそれが 控こっている。このことは海馬についても同様である。 従って，に和い刺激で動物に眼振を誘発しらる条件とし てこれらの脳分野の adrenergic components の活動性え 進は重視すべきであるとの私達の考光は妥当である。因 みに，海馬や中隔野はそれぞれ adrenergic components そ cholinergic components を有している(小池上 $1965 \mathrm{c}$ ， Gilgis 1967, Tyrer 1968, Hashimoto et al, 1962)。但 し, この 2 つ脳分野に反覆電気刺激を加光る場合, 前 者では adrenaline 耐性の低下がもたらされやすく，後 者ではそれが抗こりがたい。どの様な理由でこの様な差 が生じたか, 興味ある事実で, 今後の研究課題とした W。

最後に手綱核とに沶い刺激で扣こる眼振に関連してこ れ束で報告を紹介して打きたい。サルの嗅粘膜に polyomyelitis の virus を直接接種した実驗によると, 変性は唤結節, 対角帯核, 梨状葉前野, 扁桃核周辺皮 質，視床下部，視床中央線核，手綱核，淡䓟球などにみ られるといら（Bodian 1950)。また，手綱核は視床髅条 を経て海馬.中隔核，嗅結節，外側視束前野，扁桃核と 梨状葉の前部, 外側視床下部などから線維を受けている (Niedzielska 1966)。

従って, 手網核は嗅受容器よりの求心性線維を直接受 けるとこるではないとしても, 嗅覚に関連する他の大脳 辺縁系と深いかかわりを多つ脳分野と考它てよい。この ことは,この核が嗅覚求心系と脳幹平衡中枢をさすぶ経 路中の中継核として重要な役割を果す可能性を示してい る。

さて，今回の契験では手綱核に反覆電気刺激を加える と，動物はにおい刺激に過敏となりこの刺激で高率に 眼振を誘発又は増強するよらになる( 5 羽中 4 羽, $80 \%$ )。 また，これらの動物は全例 adrenaline 耐性を低下し, 本薬剤の静注により眼振を誘発又は增強している.

House, Pansky (1967 b) は嗅受容器と脳幹及び脊噵 をむすぶ神経路として次の考えをのべている。すなわ

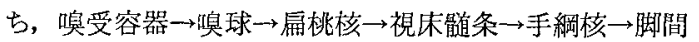
核路 $\rightarrow$ 脚間核 $\rightarrow$ 脳幹 (Gudden 核) $\rightarrow$ Schütz 背側縦束 $\rightarrow$ 脳幹及び求䯣の somatic 及び autonomic な運動核一眼 筋, 骨格筋, 自律器官。 
もらるん，屠桃核と脳幹平衡中权を結ぶ神経回路はと れ以外飞も市り, 単純ではない。従って, 手網核の他に どのような中継核がさらに重要であるかは今後の課題と い克る。

IV. よ め

(1) 海馬反覆電気刺激ウサギでは, adrenaline 耐性を 低下しこの薬剤の静注により眼振を誘発又は増強する ことが多かった。これらの動物にに怙い刺激を加える と，その一部汇眼振の增強や減少が括こった。

(2) 扁兆核外側部反覆電気刺激ウサギでは，adrenalineを静注してもにおい刺激をあた劣ても，眼振を誘発 又は增強することはなかった。

（3）中隔野反覆電気刺澈ウサギでは, adrenaline 静注 で眼振の增強をみるるのがあった。この動物は汇括い刺 激により眼振の增強がみられた。但しこの様なウサギ は少数であった。

（4）手綱核反覆電気刺激ウサギでは, adrenaline 静注 に上り眼振の誘発, 增強が招こる頻度が高かった。生 た,この上らな動物はに抋い刺激により眼振が誘発又は 增強される頻度が高かった。

以上の成績やこれまで私達が得た動物実験の成績上 り，次の考光をのべた。

(1) に括い刺激で誘発される眼球の平衡障書 (眼振) の機序に扇佻核内側部之手綱核は重要な関連を有する。 これに対し，海馬，中隔核はこの反射関係があるとし ても主役を演ずるものではない。また，扁桃核外側部は 飞括い刺激で扢こる眼球平衡障害に有意の連関を有する 核とは考学がたい。

(2) に出い刺激で眼球の平衡障害が敊こる条件とし $\tau$, 中枢神経系, とくに扇桃核, 手絴核の adrenergic components の hyperreactivity 忹重要である。

\section{考 文 献}

1) Bodian, D. : Anat. Rec., 106, 178, 1950. Cit. by 小池上春芳: 大脳辺縁系, 中外医学双書, 中外 医学社, 東京, 49, 1975。

2) Gilgis, M. : J. Comp, Neurol. $129: 85,1967$. Cit. by 小池上春芳: 大脳辺縁系, 中外医学双書, 中外医学社, 東京, 38,1965 。

3) Gloor, P. : 1955. Cit. by 小池上春芳 : 大脳辺縁 系, 中外医学双書, 中外医学社, 東京, 267-268, 1965 。

4) Hashimoto, P.H., Maeda, T., Torii, K. and Shimizu, N. : Histochemical demonstration of autonomic regions in the central nervous system of the rabbit by means of a monoamine oxidase staining. Med. J. Osaka Univ. 12:425-465, 1962.
5) House, E.L. and Pansky, B.: A functional approach to neuroanatomy. McGRAW-HILL BOOK COMPANY INC. 1967 a. Cit. by 川北 幸男, 山上栄: 機能的神経解剖学, 医歯薬出版株式 会社, 東京, 248，1975。

6) House, E. L. and Pansky, B. : A functional approach to neuroanatomy. McGRAW-HILL BOOK COMPANY INC. 220-223, $1967 \mathrm{~b}$.

7) Hinoki, M., Nakanishi, K., et al. : Studies on nystagmus elicited from hippocampus in rabbits; with reference to EEG's and autonomic responseș. Agressologie, 19, $3: 187-195,1978$.

8）㭘学, 中西和仁，他：に拈い刺激で誘発されるめま 心.平衡失調; 神経耳科学的考察。耳鼻臨床, 74 : 増 1, 537-563, 1981.

9) Holmes, R.L. and Sharp, J.A. : The human nervous system; A developmental approach. J. \& A. CHURCHILL LTD, LONDON, 1969. Cit. by 作田勉: 神経解剖学; 発生学的アプローチと機 能。医学書院, 東京, 87, 1972。

10) Kaada, B. R. : Somato-motor, autonomic and electrocorticographic responses to electrical stimulation of "Rhinencephalic" and other structures in primates, cat and dog. Acta Physiol. Scand. 24 (Suppl. 83) 24-37, 1951.

11）Kaada, B. R., et al. : 1954. Cit. by 小池上春芳 : 大脳辺縁系, 中外医学双書, 中外医学社, 東京, $267-268,1965$ 。

12）小池上春芳 : 辺縁系と運動一特飞解剖学的関保。腷 之神経，14，541-549，1962。

13）小池上春芳: 大脳辺縁系, 中外医学双書, 中外医学 社, 東京, 104, $1965 \mathrm{a}, 267-268,1965 \mathrm{~b}, 36$, $1965 \mathrm{c}$ 。

14）小池上春芳：大脳边縁系, 中外医学双彗, 中外医学 社, 東京, $47,1975 \mathrm{a}, 49,1975 \mathrm{~b}$ 。

15) Magnus, L. and Lammers, H. J. : 1956. Cit. by 小池上春芳 : 大脳边縁系, 中外医学双書, 中学医学 社, 東京, 267-268, 1965。

16) Meyer, M. and Allison, A.C. : J. Neurol. Neurosurg. Psychiat., 12, 274, 1949. Cit. by 小池上 春芳: 大脳辺縁系, 中外医学双書, 中外医学社, 東京, 48,1975 。

17）中西和仁：大脳辺縁系々眼運動系の機能的協関に関 する実験的考察; 海馬電気刺激でおこる脳波の変動 を指標とする観察。耳鼻臨床，69：增 3，15551588,1976 。

18）中西和仁, 檜学, 他 : 神経の化学伝達物質に対する 
反応からみた海馬起源の眼球運動; 海馬へのアドレ ナリン，カルバコール注射で誘発される脳波々眼球 運動を指標とする分析, Equilibrium Res. $37: 6$, 1978 。

19）中西和仁, 檜学, 他: 海馬起源の眼振解発における 乳頭体之透明中隔の役割; 乳頭体之透明中隔反覆電 気刺激ウサギでみられるアドレナリン眼振を指標と する锶察。Equilibrium Res. 37(2), 221-227, 1978 。

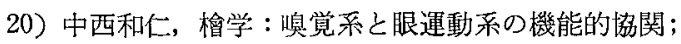
嗅刺激により誘発される眼球運動を指標とする分 析。 Equilibrium Res. $38: 1-7,1979$.

21) Niedzielska, B. : Acta Biol. Exper. (Warsaw), 26，149，1966. Cit. by 小池上春芳 : 大脳辺縁系, 中外医学双售, 中外医学社, 東京, 90, 1975 。

22）高木貞敬：嗅覚について。耳鼻と臨床，25:629638,1979 。

23) Tyrer, J.H., Eadie, M. J. and Kukums, J.R.: Histochemical measurements of relative concentrations of monoamine oxidase in various regions of rabbit brain. Brain Res. $91: 507-518,1968$.

Cit. by 小池上春芳 : 脳の解剖学 (岡本道雄, 草間 敏夫編), 朝倉書店, 東京, 493, 1971。

24) Ursin, H. and Kaada, B.R. : 1960. Cit. by 小 池上春劳: 大脳辺縁系, 中外医学双書, 中外医学 社, 東京, 267-268, 1965。

\footnotetext{
Abstract

In order to investigate the neural mechanism of olfaction-related nystagmic response, a series of experiments has been carried out where various parts of rabbits' brains received repeated electrical stimulation. The resulting changes in nystagmic responses of the animals were observed, when they were stimulated by intravenous adrenaline and inhalation of the vapor of liquid garlic.

The results obtained were as follows :

(1) The rabbits receiving repeated electrical stimulation of the hippocampus tended to develop and /
}

or increase nystagmic response with intravenous adrenaline. In some of them, increase and / or decrease of nystagmic responses were also seen in response to inhalation of the vapor of liquid garlic.

(2) The rabbits receiving repeated electrical stimulation of the lateral portion of the amygdaloid nucleus did not show any signs of nystagmic response with intravenous adrenaline. The same held true for inhalation of the vapor of liquid garlic.

(3) One rabbit receiving repeated electrical stimulation of the septal area had an increased nystagmic response with intravenous adrenaline. This animal also had an increased nystagmic response when he was stimulated by inhalation of the vapor of liquid garlic.

(4) The rabbits receiving repeated electrical stimulation of the habenular nucleus had significant development and/or increase of nystagmic response when intravenous adrenaline was given. These animals also developed similar nystagimic response with inhalation of the vapor of liquid garlic.

With reference to the above-mentioned results and those from our previous animal experiments, the following conclusions were drawn :

(1) The medial portion of the amygdaloid nucleus and habenular nucleus play a major role in the production of olfaction-related nystagmic response. In contrast, the roles of the hippocampus and septal area in induction of nystagmic responses due to olfaction were less obvious. No significant role of the lateral portion of the amygdaloid nucleus was attributable in the production of the nystagmus of this kind.

(2) Overexcitement of adrenergic components in the central nervous system, particularly those involved in the medial portion of the amygdaloid nucleus and habenular nucleus is an important factor for the production of olfaction-related ocular dysfunction, $i$. e. nystagmus. 